\title{
Fluorescence Sensing of Anions Based on Inhibition of Excited-State Intramolecular Proton Transfer
}

Yunkou Wu, Xiaojun Peng ${ }^{*}$, Jiangli Fan, Shang Gao, Maozhong Tian, Jianzhang Zhao and Shiguo Sun

State Key Laboratory of Fine Chemicals, Dalian University of Technology, 158 Zhongshan Road, Dalian 116012, P.R. China

Contents of Supporting Information

S2. Determination of quantum yields

S2. Crystal data of TABO

S3. Determination of equilibrium constants

S4. Absorbance titration spectra of TABO with the addition of $\mathrm{CH}_{3} \mathrm{COO}^{-}$and $\mathrm{H}_{2} \mathrm{PO}_{4}^{-}$

S5. Job's plot for TABO interaction with $\mathrm{CH}_{3} \mathrm{COO}^{-}$

S5. Absorbance, ${ }^{1} \mathrm{H}$ NMR and fluorescence titration spectra of TABO with the addition of $\mathrm{Cl}^{-}$

S7. Absorbance titration spectra of $\mathrm{PUBO}$ with the addition of $\mathrm{CH}_{3} \mathrm{COO}^{-}$and $\mathrm{H}_{2} \mathrm{PO}_{4}^{-}$

S8. Fluorescence titration spectra of $\mathrm{TABO}$ with the addition of $\mathrm{CH}_{3} \mathrm{COO}^{-}$and $\mathrm{H}_{2} \mathrm{PO}_{4}^{-}$

S9. ${ }^{1} \mathrm{H}-{ }^{1} \mathrm{H}$ COSY spectra of TABO and PUBO 


\section{Determination of quantum yields}

Quantum yields were determined by the relative comparison procedure. ${ }^{1}$ The absorption band maxima of standard and unknown samples were adjusted below 0.1. Corrected emissions were recorded with a PTI-700 fluorimeter for quantum yields determination (emission correction file provided by instrument manufacturer). The quinine sulfate with the quantum yields of 0.51 in sulfuric acid (0.05 M) was used as the standard. The general equation used in the determination of relative quantum yields is shown as follows:

$$
Q_{u}=\frac{Q_{s} \times F_{u} \times A_{s} \times \lambda_{e x s} \times \eta_{u}^{2}}{F_{s} \times A_{u} \times \lambda_{e x u} \times \eta_{s}^{2}}
$$

Where $Q$ is the quantum yields; $F$ is the integrated area under the corrected emission spectrum; $A$ is the absorbance at the excitation wavelength; $e x$ is the excitation wavelength; $\eta$ is the refractive index of the solution; and the subscripts $u$ and $s$ refer to the unknown and the standard, respectively.

\section{Crystal data of TABO}

The X-ray data were collected on a Bruker P4 fourcircle diffractor using graphite monochromated Mo-K $\alpha$ radiation $(\lambda=0.71073 \AA)$. The structure was solved by the direct methods and refined using SHELX97 programs. ${ }^{2}$ All non-hydrogen atoms were refined anisotropically. Hydrogens bonded to carbon atoms were placed at calculated positions with the appropriate AFIX instructions and refined using a riding model. Hydrogen bonded to the nitrogen was located in the difference Fourier map and refined further.

Table 1. Crystal data for TABO

\begin{tabular}{ll}
\hline formula & $\mathrm{C}_{20} \mathrm{H}_{16} \mathrm{~N}_{2} \mathrm{O}_{3} \mathrm{~S}$ \\
molecular weight & 364.42 \\
color & colorless \\
crystal size $(\mathrm{mm})$ & $0.40 \times 0.32 \times 0.12$ \\
crystal system & Triclinic \\
space group & $\mathrm{P}-1$ \\
$a(\AA)$ & $8.339(6)$ \\
$b(\AA)$ & $9.815(7)$ \\
$c(\AA)$ & $11.245(8)$ \\
$\beta($ deg $)$ & $87.713(10)$ \\
\hline
\end{tabular}




\begin{tabular}{|c|c|}
\hline$V\left(\AA^{3}\right)$ & $875.3(11)$ \\
\hline$Z$ & 2 \\
\hline calculated density $\left(\mathrm{Mg} / \mathrm{m}^{3}\right)$ & 1.383 \\
\hline $\mathrm{F}(000)$ & 380 \\
\hline rature $(\mathrm{K})$ & 273(2) \\
\hline$\theta$ ral & 2.18 to 29 \\
\hline refle & 10533 \\
\hline indep & 4273 \\
\hline$R_{\text {int }}^{\mathrm{a}^{\mathrm{a}}}$ & 0.0182 \\
\hline R1, wR2 (strong data) ${ }^{b}$ & $0.0388,0.1086$ \\
\hline R1, wR2 (all data) ${ }^{b}$ & $0.0442,0.1140$ \\
\hline $\mathrm{GOF}^{\mathrm{c}}$ & 1.051 \\
\hline \multicolumn{2}{|c|}{$\begin{array}{l}{ }^{\mathrm{a}} R_{\text {int }}=\sum\left|F_{\mathrm{o}}{ }^{2}-F_{\mathrm{o}}{ }^{2}(\operatorname{mean})\right| / \sum F_{\mathrm{o}}{ }^{2} \cdot{ }^{\mathrm{b}} \mathrm{R} 1=\sum \| F_{\mathrm{o}} \mid- \\
\left|F_{\mathrm{c}} \| /\right| \sum\left|F_{\mathrm{o}}\right|, \quad \text { wR2 }=\left[\sum\left[w\left(F_{\mathrm{o}}{ }^{2}-F_{\mathrm{c}}\right)^{2}\right] \mid /\right. \\
{\left[\sum \mathrm{w}\left(\left(F_{\mathrm{o}}{ }^{2}\right)^{2}\right]\right]^{1 / 2} \cdot{ }^{\mathrm{c}} \mathrm{GOF}=\left\{\left[\sum\left[w\left(F_{\mathrm{o}}{ }^{2}-F_{\mathrm{c}}{ }^{2}\right)^{2}\right] / /(n-\right.\right.} \\
p)\}^{1 / 2}, \text { where } n \text { is the number of reflections and } p \\
\text { is the number of parameters refined. }\end{array}$} \\
\hline $\begin{array}{l}\text { Selected bond lengths }(\AA) \\
0.818(17), \mathrm{N} 2-\mathrm{H} 12.019(18), \\
1.406(2), \mathrm{C} 1-\mathrm{C} 71.455(2), \mathrm{N} 2 \\
1.3978(19), \mathrm{O} 3-\mathrm{C} 71.3654(19) \\
1.6319(16) ; \mathrm{C} 1-\mathrm{C} 2-\mathrm{N} 1118.82( \\
\mathrm{N} 1-\mathrm{H} 1-\mathrm{N} 2143.1(16), \mathrm{C} 2-\mathrm{C} 1-\mathrm{C}\end{array}$ & $\begin{array}{l}\mathrm{d} \text { angles }\left(^{\circ}\right): \mathrm{N} 1-\mathrm{H} 1 \\
\text {-C2 } 1.412(2), \mathrm{C} 1-\mathrm{C} 2 \\
7 \quad 1.2989(19), \mathrm{N} 2-\mathrm{C} 13 \\
\text { O3-C8 1.378(2), } \mathrm{S} 1-\mathrm{N} 1 \\
) \text { C2-N1-H1 114.4(12), } \\
121.70(13), \mathrm{N} 2-\mathrm{C} 7-\mathrm{C} 1\end{array}$ \\
\hline $\begin{array}{l}128.96(13), \quad \mathrm{N} 2-\mathrm{C} 7-\mathrm{O} 3 \\
104.30(11), \quad \mathrm{C} 7-\mathrm{N} 2-\mathrm{C} 13 \\
107.96(13), \mathrm{C}(8)-\mathrm{C}(13)-\mathrm{N}(2)\end{array}$ & $\begin{array}{l}4.46(12), \quad \text { C7-O3-C8 } \\
.99(12), \\
28(14) .\end{array}$ \\
\hline
\end{tabular}

\section{Determination of equilibrium constants}

From the expression presented in eq 1, 4, 5 and 6 , it is found that the stepwise equilibrium constants of them fit 1:1 model for substrate-ligand interaction. If the UV/Vis titration spectra are used for the equilibrium constants determination, the binding isotherm is shown as follows: ${ }^{3}$

$$
\frac{\Delta A}{b \times S \times \Delta \varepsilon}=\Delta A_{N}=\frac{K \times[L]}{1+K \times[L]}
$$

Where $A$ is the absorbance; $b$ is the length of sample cell; $S$ is the total concentration of substrate; $\varepsilon$ is extinction coefficients; $\Delta A_{N}$ is the normalized absorbance changes $\Delta A /\left(A_{\max }-A_{\min }\right) ; K$ is the equilibrium constants; $[L]$ is the free ligand concentration and the approximation $[L] \approx L$ is made in most cases. The equilibrium constants for eq 1 and eq 6 give proton-dissociation $K_{\mathrm{d}}$, while the equilibrium constants for eq 4 and eq 5 give the association constants $K_{\mathrm{a}}$. For example, the $\mathrm{F}^{-}$titration data in Figure S1c fitted directly with the above equation using nonlinear regression software Origin give the proton-dissociation 
$K_{\mathrm{d}}$ or the semilogarithmic plots of $\Delta A_{N}$ against $-\log [L]$ fitted with Sigmoidal give $\log K_{\mathrm{d}}$ for TABO interaction with $\mathrm{F}^{-}$in the first step.

\section{Absorbance titration spectra of TABO with the addition of $\mathrm{CH}_{3} \mathrm{COO}^{-}$and $\mathrm{H}_{2} \mathrm{PO}_{4}{ }^{-}$}

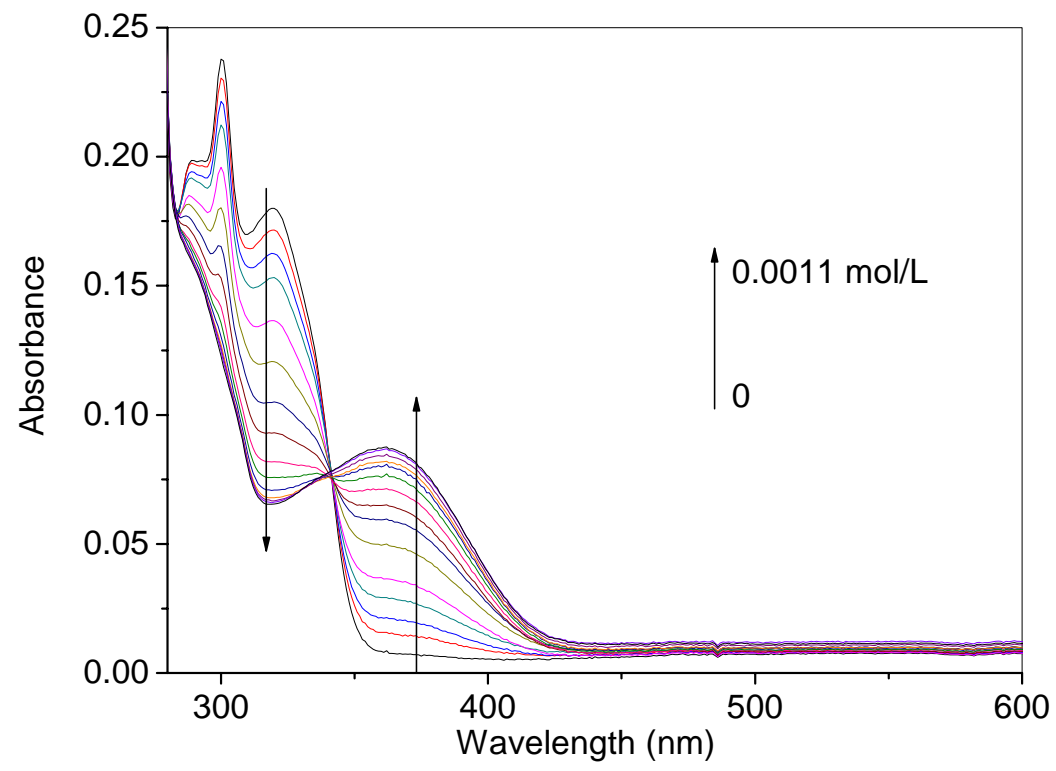

Figure S1a. Changes in absorbance spectra for TABO $\left(1.0 \times 10^{-5} \mathrm{M}\right)$ in DMSO with the addition of $\left[(\mathrm{Bu})_{4} \mathrm{~N}^{-} \mathrm{CH}_{3} \mathrm{CO}_{2}\right.$ from 0 to $0.0011 \mathrm{M}$.

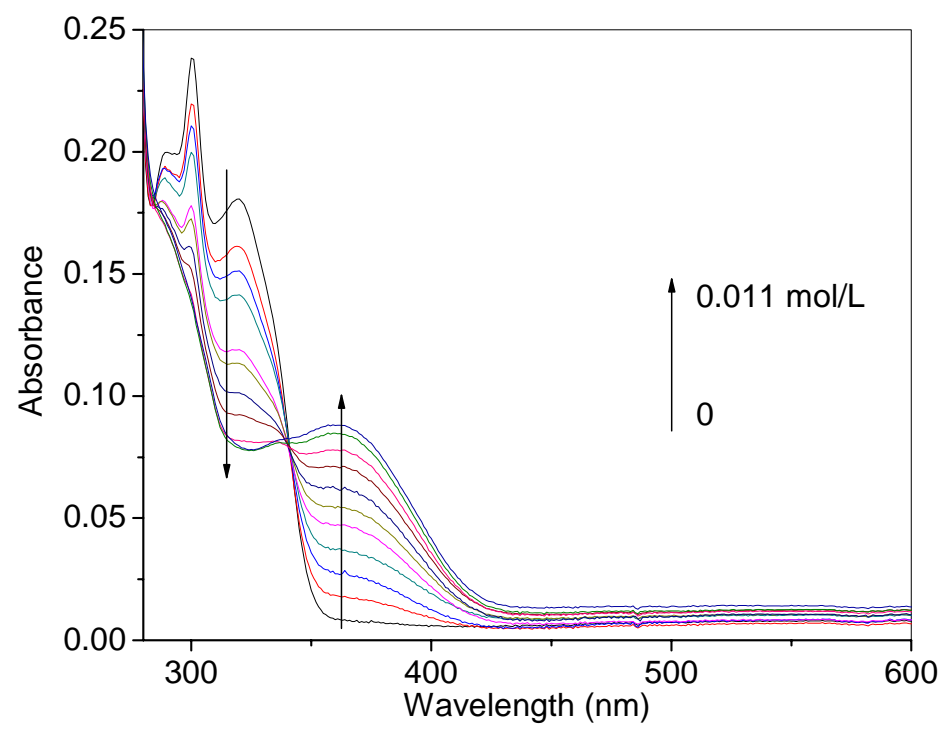

Figure S1b. Changes in absorbance spectra for TABO $\left(1.0 \times 10^{-5} \mathrm{M}\right)$ in DMSO with the addition of $\left[(\mathrm{Bu})_{4} \mathrm{~N}\right] \mathrm{H}_{2} \mathrm{PO}_{4}$ from 0 to $0.011 \mathrm{M}$. 


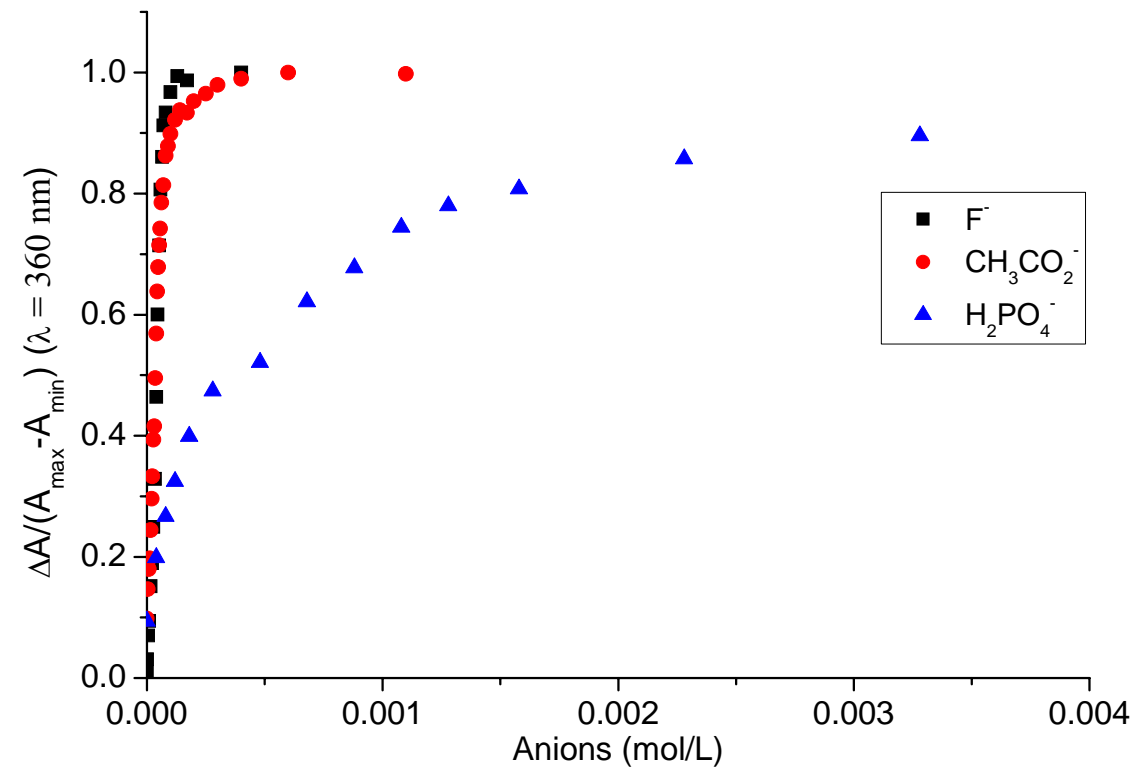

Figure S1c. Normalized absorbance changed at $360 \mathrm{~nm}$ for TABO $\left(1.0 \times 10^{-5} \mathrm{M}\right)$ in DMSO versus the concentration of anions.

Job's plot for TABO interaction with $\mathrm{CH}_{3} \mathrm{COO}^{-}$

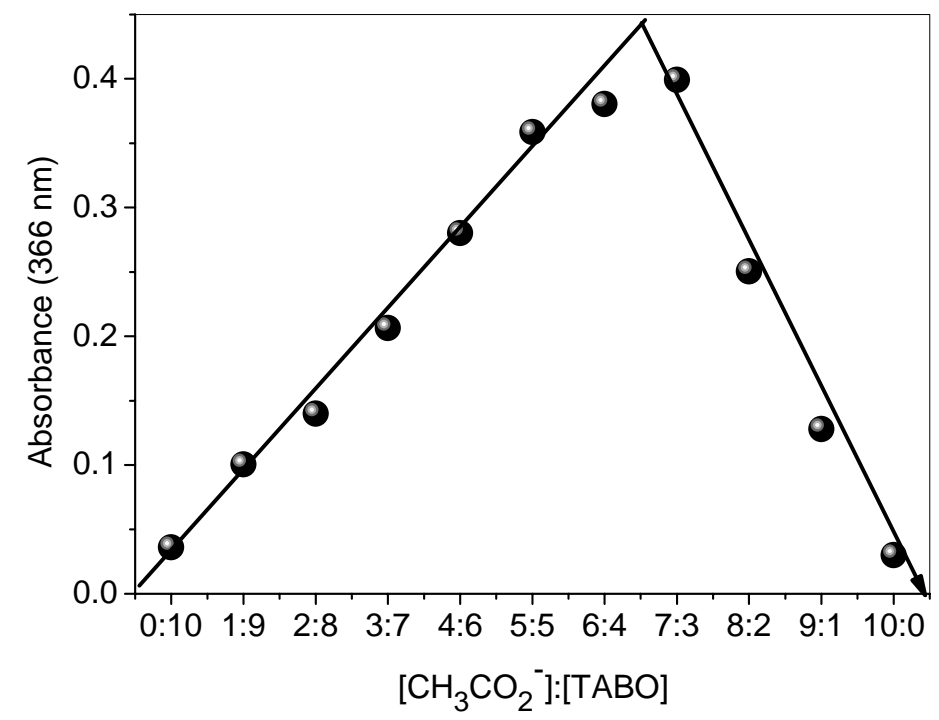

Figure S2. Job's Plot for $\mathrm{CH}_{3} \mathrm{COO}^{-}$and TABO interaction, the total $\left[\mathrm{F}^{-}\right]+[\mathrm{TABO}]=2.0 \times 10^{-4} \mathrm{M}$.

Absorbance, ${ }^{1} \mathrm{HNMR}$ and fluorescence titration spectra of TABO with the addition of $\mathrm{Cl}^{-}$ 


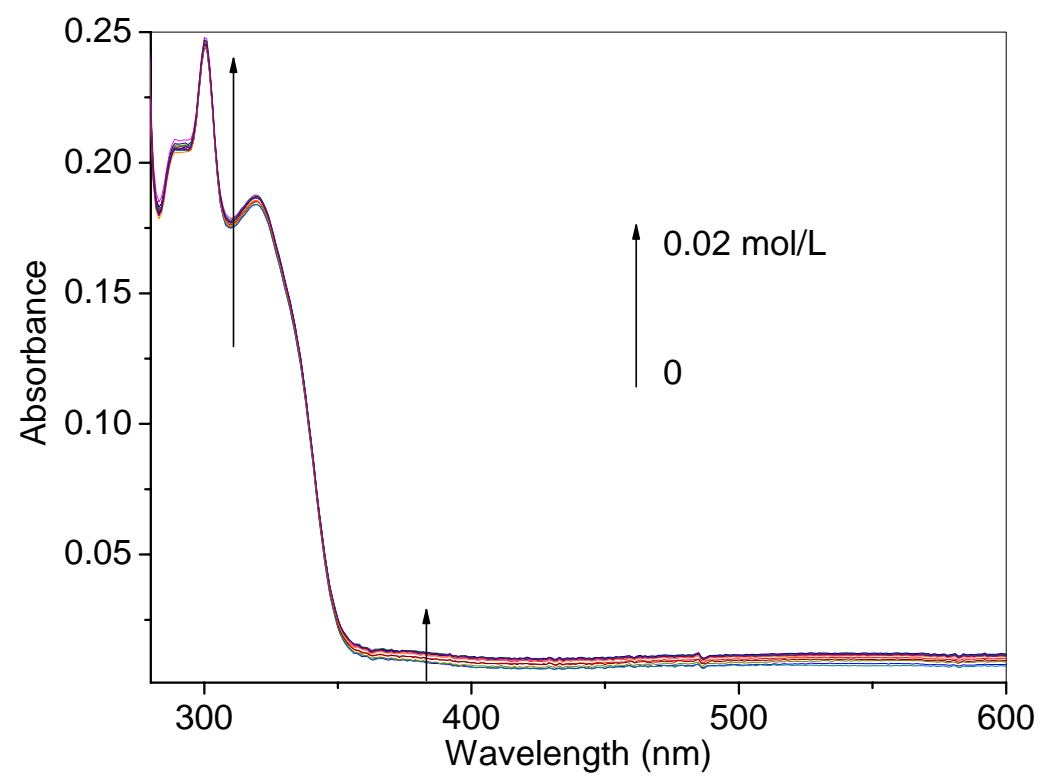

Figure S3a. Changes in absorbance spectra for TABO $\left(1.0 \times 10^{-5} \mathrm{M}\right)$ in DMSO with the addition of $\left[(\mathrm{Bu})_{4} \mathrm{~N}\right] \mathrm{Cl}$ from 0 to $0.02 \mathrm{M}$.

Though $\mathrm{Cl}^{-}$cannot induce an observable spectral change in absorbance (Figure S3a), the sulfonamide-chloride hydrogen-bond formation can be detected from the NMR titration (Figure S3b). For the ${ }^{1} \mathrm{H}$ NMR spectrum, two effects are responsible for the ${ }^{1} \mathrm{H}$ NMR changes upon NH-anion hydrogen-bond formation:(1) through-bond effects, which increase the electron density of the phenyl ring and promote an upfield shifts, and (2) through-space effects, which polarize C-H bond in proximity to hydrogen bonds, create partial positive charge on the proton, and cause a downfield shifts. Upon addition of 10 molar equiv of $\mathrm{Cl}^{-}$, proton 4 that is in close proximity to the hydrogen bond experiences a shift to downfield due to the through-space effects. This suggests a genuine hydrogen-bond interaction is established between the $\mathrm{Cl}^{-}$and TABO (eq 4). While this hydrogen-bond formation produces minimal disturbance on the dipole associated with the charge transfer transition of TABO in the ground state, consequently only a small change is observed in the UV/Vis spectra.

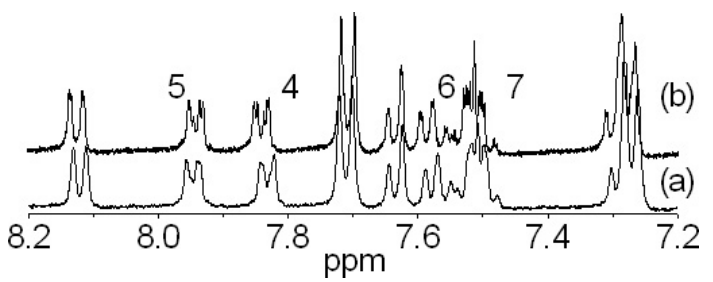


Figure S3b. Partial ${ }^{1} \mathrm{H}$ NMR $(400 \mathrm{MHz})$ spectra of TABO $\left(1.0 \times 10^{-2} \mathrm{M}\right)$ in DMSO- $d_{6}$ in (a) the absence and (b) the presence of 10.0 equiv of $\left[(\mathrm{Bu})_{4} \mathrm{~N}\right] \mathrm{Cl}$.

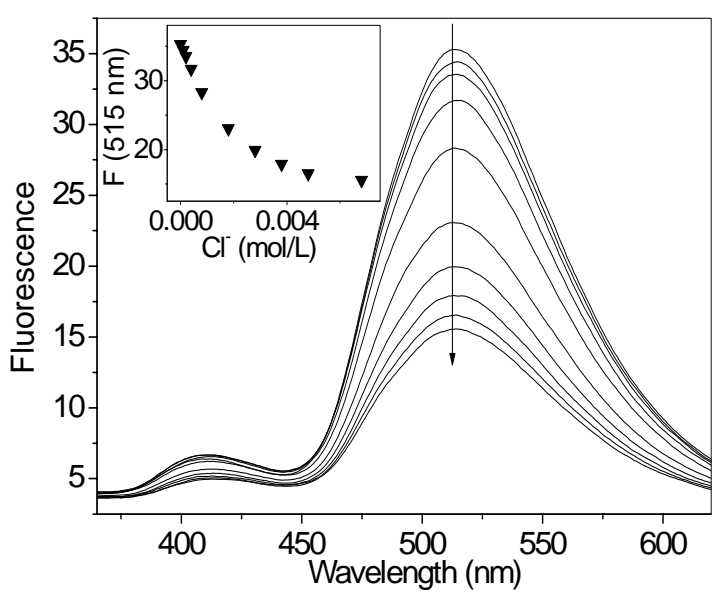

Figure S3c. Changes in fluorescent spectra $\left(\lambda_{\mathrm{ex}}=320 \mathrm{~nm}\right)$ for TABO $\left(1.0 \times 10^{-5} \mathrm{M}\right)$ in DMSO with the addition of a standard solution of $\left[(\mathrm{Bu})_{4} \mathrm{~N}\right] \mathrm{Cl}$ from 0 to $0.006 \mathrm{M}$. Inset: fluorescence changed at $515 \mathrm{~nm}$ versus concentration of $\mathrm{Cl}^{-}$.

\section{Absorbance titration spectra of $\mathrm{PUBO}$ with the addition of $\mathrm{CH}_{3} \mathrm{COO}^{-}$and $\mathrm{H}_{2} \mathrm{PO}_{4}{ }^{-}$}

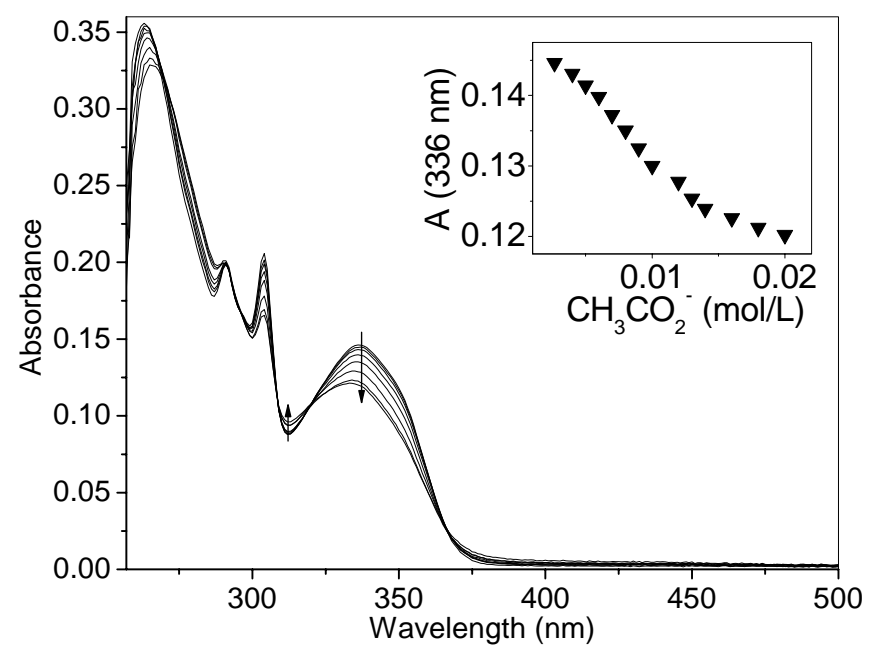

Figure S4a. Changes in absorbance spectra for PUBO $\left(1.0 \times 10^{-5} \mathrm{M}\right)$ in DMSO with the addition of $\left[(\mathrm{Bu})_{4} \mathrm{~N}\right] \mathrm{CH}_{3} \mathrm{CO}_{2}$ from 0 to $0.02 \mathrm{M}$. Inset: absorbance changed at $336 \mathrm{~nm}$ versus concentration of $\mathrm{CH}_{3} \mathrm{CO}_{2}{ }^{-}$. 


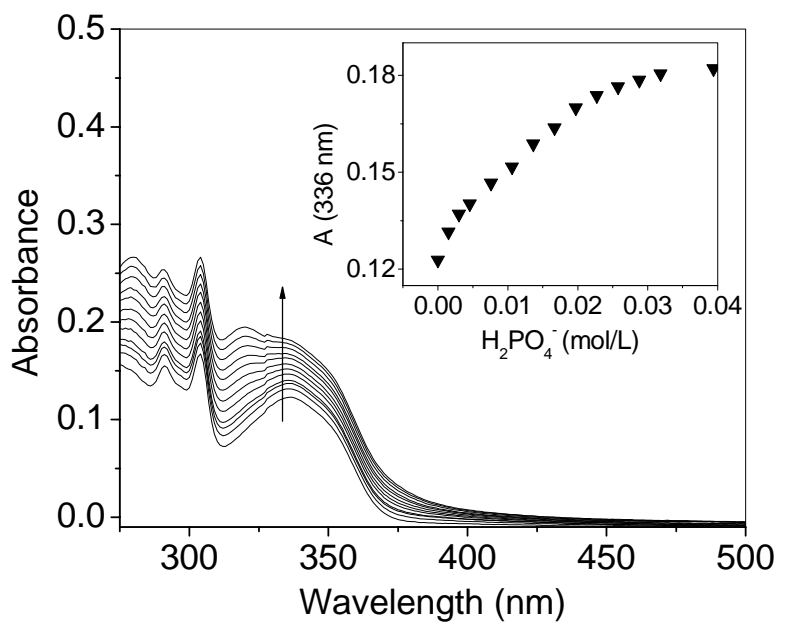

Figure S4b. Changes in absorbance spectra for PUBO $\left(1.0 \times 10^{-5} \mathrm{M}\right)$ in DMSO with the addition of $\left[(\mathrm{Bu})_{4} \mathrm{~N}^{-} \mathrm{H}_{2} \mathrm{PO}_{4}\right.$ from 0 to $0.04 \mathrm{M}$. Inset: absorbance changed at $336 \mathrm{~nm}$ versus concentration of $\mathrm{H}_{2} \mathrm{PO}_{4}{ }^{-}$.

\section{Fluorescence titration spectra of TABO with the addition of $\mathrm{CH}_{3} \mathrm{COO}^{-}$and $\mathrm{H}_{2} \mathrm{PO}_{4}{ }^{-}$}

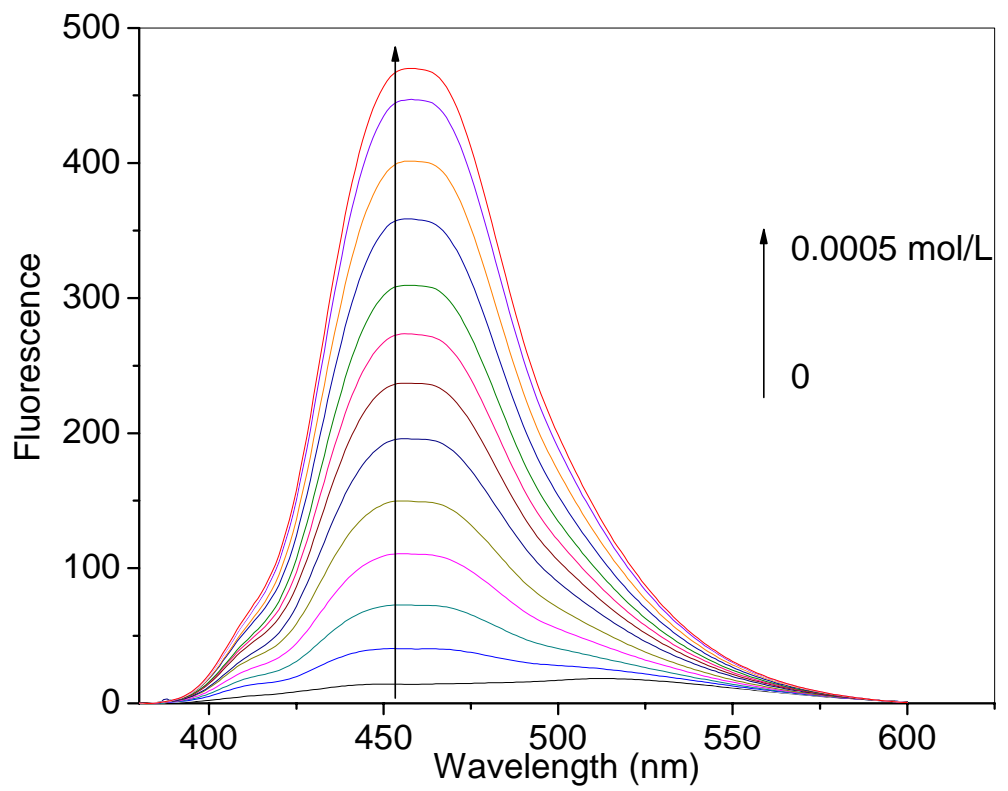

Figure S5a. Changes in fluorescence spectra $\left(\lambda_{\mathrm{ex}}=320 \mathrm{~nm}\right)$ for TABO $\left(1.0 \times 10^{-5} \mathrm{M}\right)$ in DMSO with the addition of $\left[(\mathrm{Bu})_{4} \mathrm{~N}\right] \mathrm{CH}_{3} \mathrm{CO}_{2}$ from 0 to $0.0005 \mathrm{M}$. 


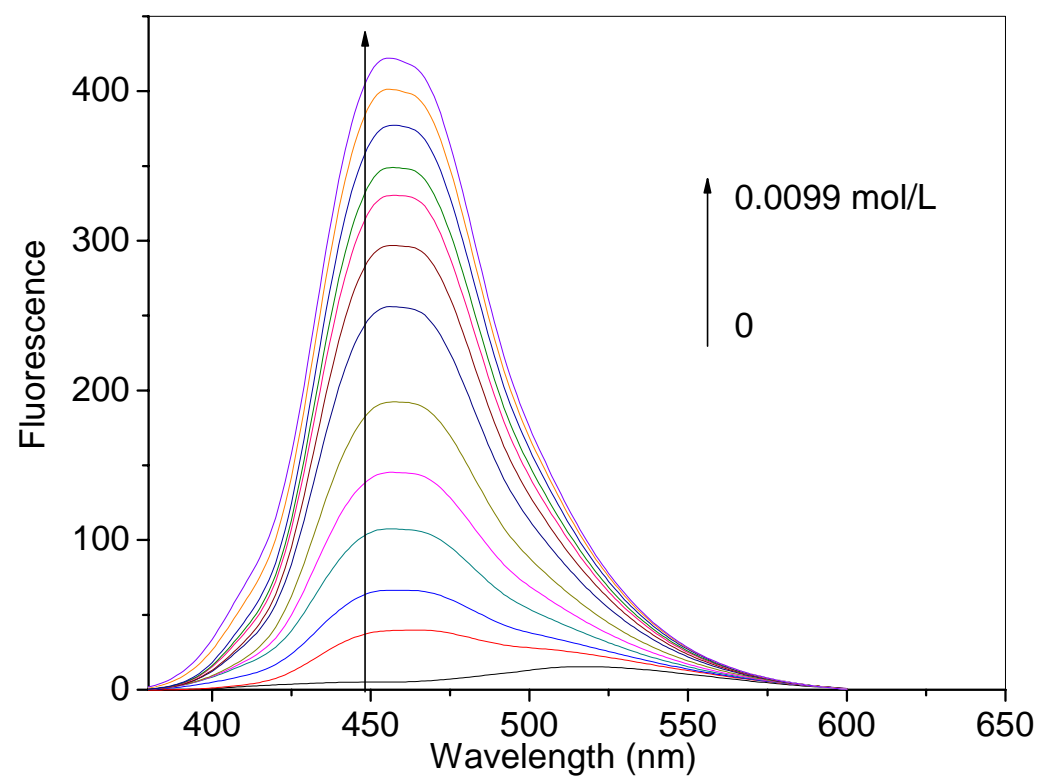

Figure S5b. Changes in fluorescence spectra $\left(\lambda_{\mathrm{ex}}=320 \mathrm{~nm}\right)$ for TABO $\left(1.0 \times 10^{-5} \mathrm{M}\right)$ in DMSO with the addition of $\left[(\mathrm{Bu})_{4} \mathrm{~N}\right] \mathrm{H}_{2} \mathrm{PO}_{4}$ from 0 to $0.0099 \mathrm{M}$.

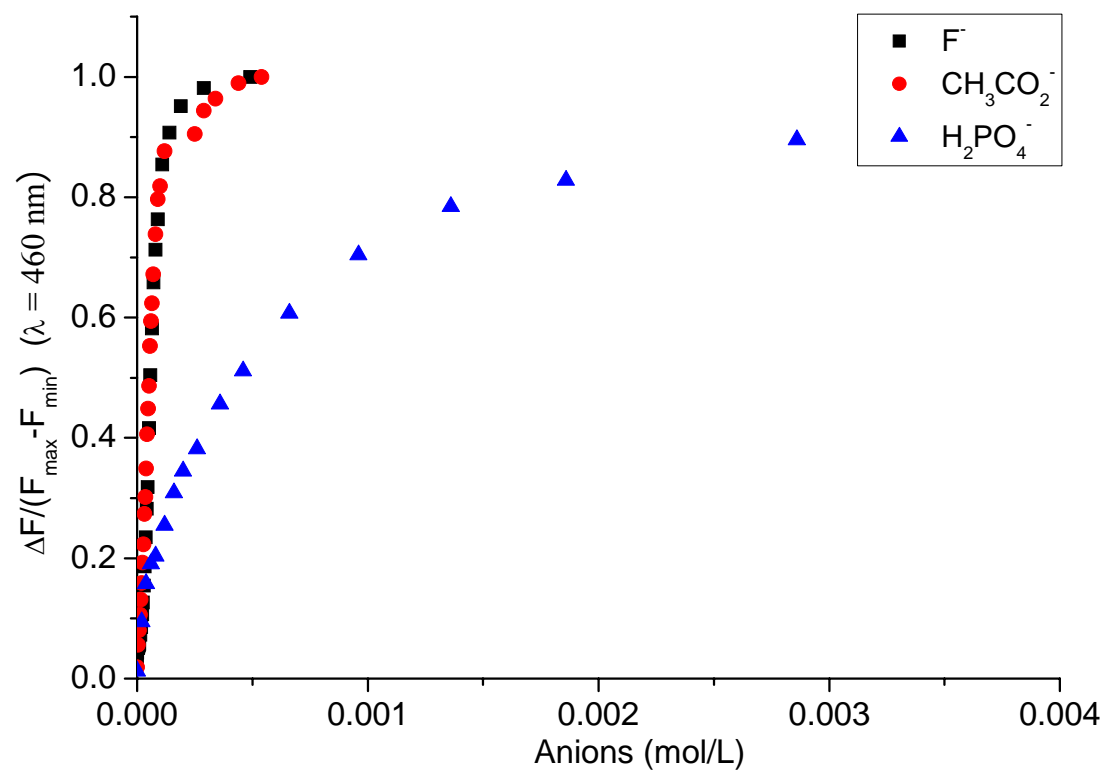

Figure S5c. Normalized fluorescence $\left(\lambda_{\mathrm{ex}}=320 \mathrm{~nm}\right)$ changed at $460 \mathrm{~nm}$ for TABO $\left(1.0 \times 10^{-5} \mathrm{M}\right)$ in DMSO versus the concentration of anions.

\section{${ }^{1} \mathrm{H}-{ }^{1} \mathrm{H}$ COSY spectra of TABO and PUBO}



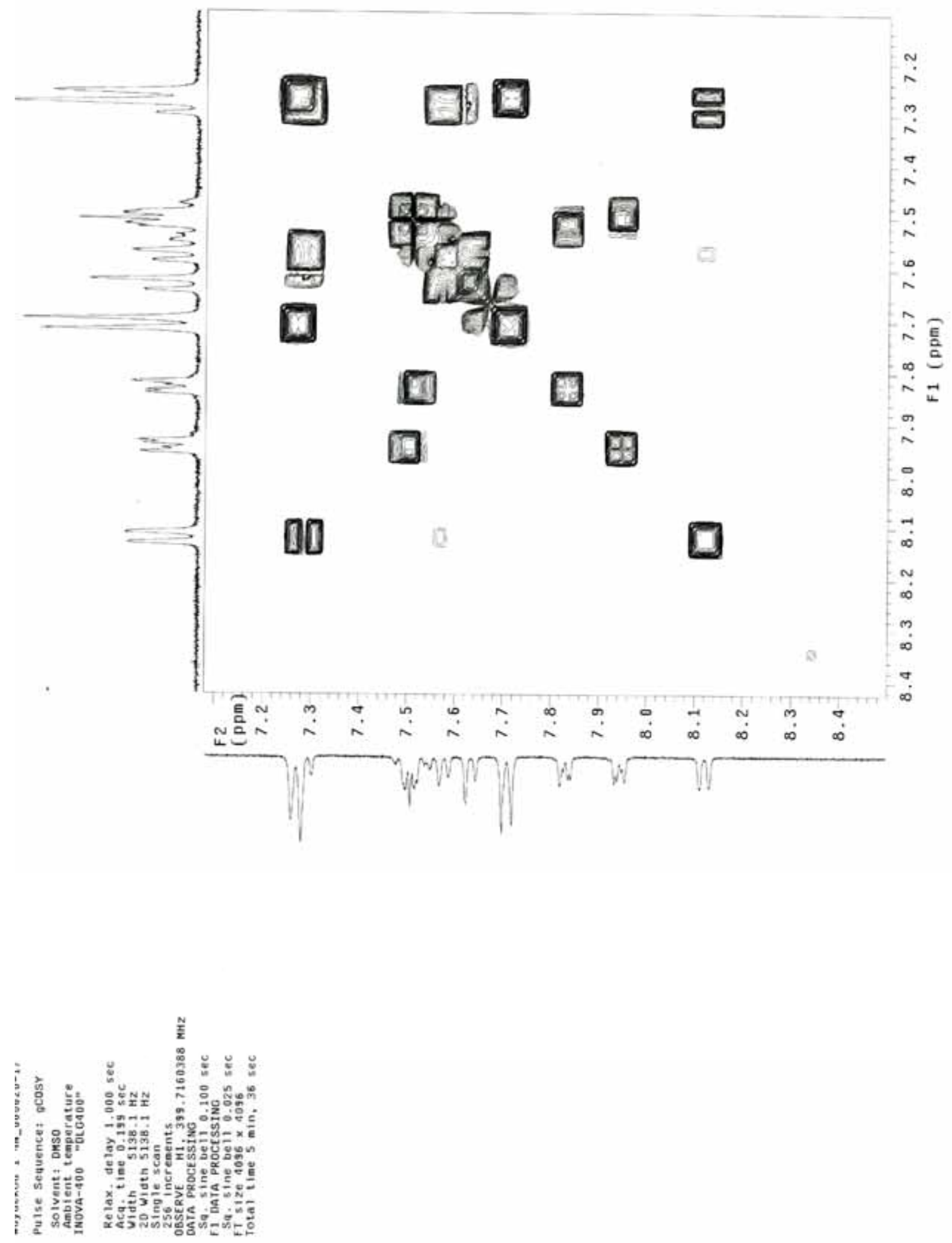

Figure S5a. ${ }^{1} \mathrm{H}-{ }^{1} \mathrm{H}$ COSY spectrum of TABO $\left(1.0 \times 10^{-2} \mathrm{M}\right)$ in DMSO- $d_{6}$. 

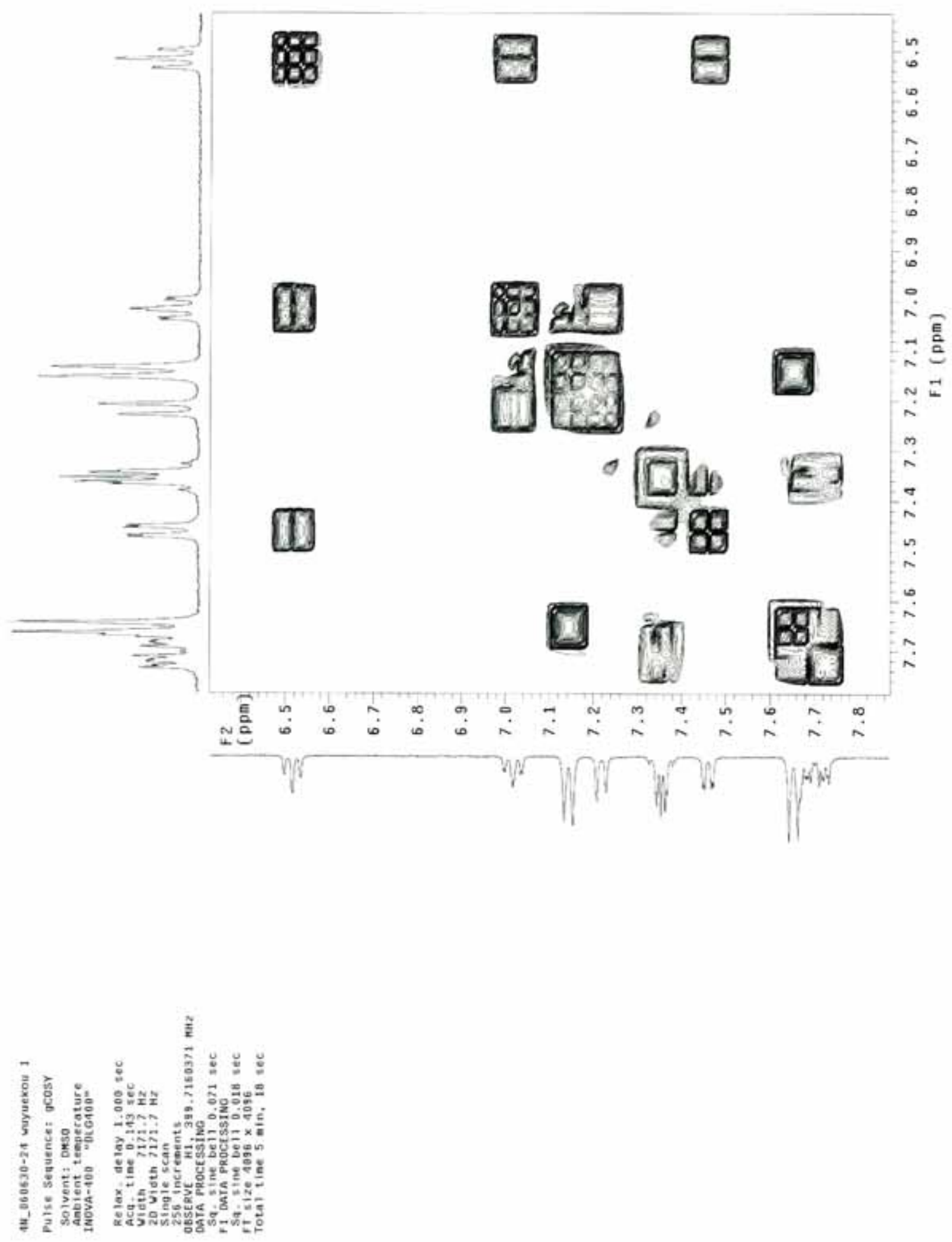

Figure S5b. ${ }^{1} \mathrm{H}-{ }^{1} \mathrm{H}$ COSY spectrum of TABO $\left(1.0 \times 10^{-2} \mathrm{M}\right)$ in DMSO- $d_{6}$ in the presence of 7.0 equiv of $\left[(\mathrm{Bu})_{4} \mathrm{~N}\right] \mathrm{F}$. 

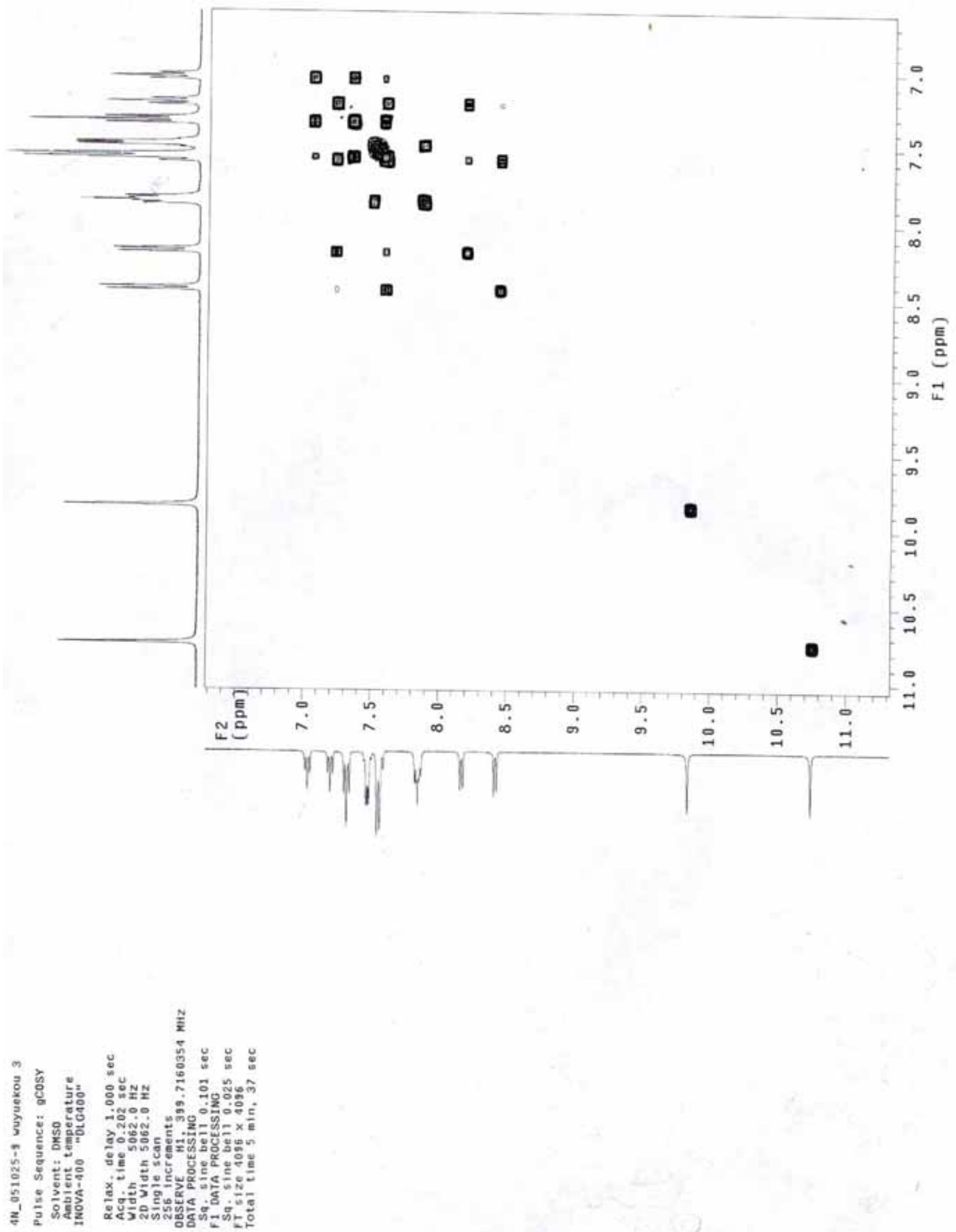

Figure S5c. ${ }^{1} \mathrm{H}-{ }^{1} \mathrm{H}$ COSY spectrum of PUBO $\left(1.0 \times 10^{-2} \mathrm{M}\right)$ in DMSO- $d_{6}$. 


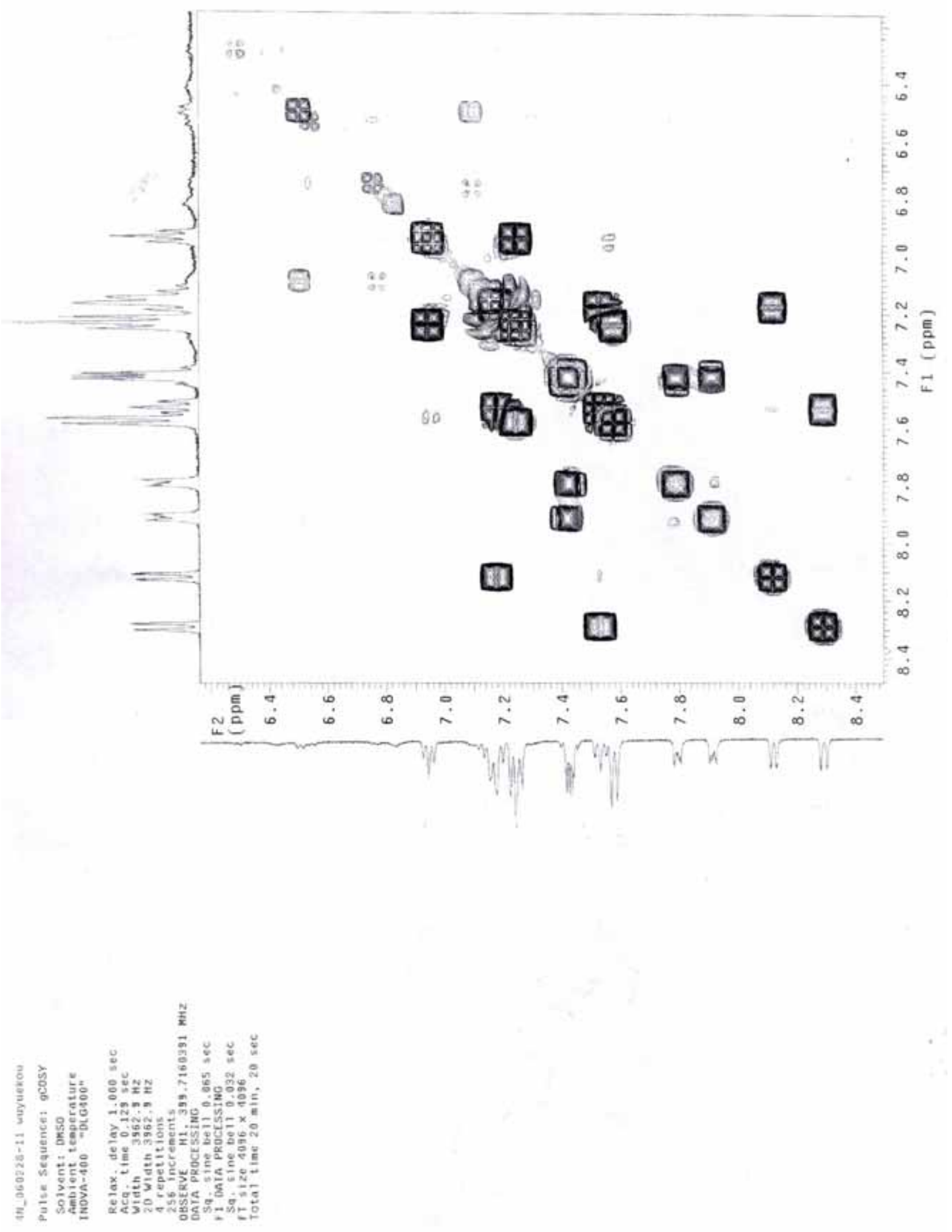

Figure S5d. ${ }^{1} \mathrm{H}-{ }^{1} \mathrm{H}$ COSY spectrum of PUBO $\left(1.0 \times 10^{-2} \mathrm{M}\right)$ in DMSO- $d_{6}$ in the presence of 7.0 equiv of $\left[(\mathrm{Bu})_{4} \mathrm{~N}\right] \mathrm{F}$. 


\section{Reference}

1. Velapoldi, R. A.; Tønnesen, H. H. J. Fluoresc. 2004, 14(4), 465-472.

2. Sheldrick, G. M. SHELXL97, Program for crystal structure determinations; University of Göttingen: Göttingen, Germany, 1997.

3. Connors, K. A. Binding Constants: the Measurement of Molecular Complex Stability. New York : Wiley, 1987; pp 21-101; 141-187. 